\title{
Research on Subject and Object in Art Management
}

\author{
Kangkang Ju \\ College of Music, Shandong University of Arts, Jinan, 250014, China \\ Hansei University, Gunpo-si, Gyeonggi-do, 435742, Korea
}

Keywords: art management; subject and object; research

\begin{abstract}
At this stage, all walks of life in China have their own management methods, which are also a management discipline worthy of deep research. As one of the emerging management disciplines, art management is gradually gaining development and attracting people's attention. In the process of its development, it has also been affected by many subject matters, such as collaboration in the process of getting along with people, cultivation of artistic creative talents, enthusiasm of management personnel for work, work efficiency, art management agents and so on. This paper analyzes the research of subject and object in art management through the analysis of the meaning, the development, the subject research and the object research in art management.
\end{abstract}

\section{Introduction}

With the rapid social and economic development of our country, the overall national strength has been greatly improved. Meanwhile, various channels of communication media have also been greatly improved. The field of artistic production has also been well applied, and more and more extensive application makes a lot of emerging art production sector is gradually formed, which is characterized by strong industrialization and enterprise. Nowadays, some universities in our country have set art management as a professional discipline, while there are still many problems, such as imperfections in the art management system and improper management methods of art management, etc. Continuous improvement and continuous development are needed. The essence of art management is to cultivate modern art talents who possess both professional art accomplishments and superb artistic appreciation skills.

\section{The Meaning of Art Management}

The essence of art management lies in the management of people. From this we can see that the most important thing in art management is the cultivation and discovery of talents and their management. A successful business is bound to have a group of outstanding people working together. The key to artistic management is the constant introduction of outstanding artistic talents in the course of the development of art work. The meaning of art management at this stage is defined as: Influence art under the influence of social economy and national policies, according to the different circumstances of each region, and through the manipulation of factors such as humanities and psychology. Art management regards the creation of works of art as a commodity, in the meantime, it controls the circulation and management of the process of commodity trading, so as to ensure the smooth flow of the art market. Art management is the bridge between the art production and the trading market, which is the only way for the art to better reach the market. At present, China's art market is gradually developing. However, generally speaking the art industry is even weaker than other cultural industries. China's art industry is still in its basic stage of development. In the face of the large art market and the impact of the mature art market abroad, our country should pay more attention to the development of the art market. A mature art market should be as follows: First, the commercialization of art; next, the scale of the art market, and then the perfect legal regulations that play a good normative role in the art market, through which a mature industrial chain of art market is 
formed.

\section{Research Object of Art Management}

In order to test the uniqueness of art management, first you need to understand a systematic viewpoint like this: most of the systems that have internal time and external structure are in the coordinates of external time and space, where the contradiction it has is generated. By studying the time relationship, one will know how it is produced, what its evolutionary process is, and what the relation within the system coordinates is. While studying the spatial relationship, we can understand the difference between it and the system's mutual restraint and interconnection. It can be seen from this that the particularity of the artistic theory system is mainly manifested in the following two aspects:

\subsection{Art management activities must abide by the objective laws of art production}

Art production is, in a certain sense, a production of a spiritual level. It still has certain similarities with the production of materials. Art management includes the production of art objects, as well as the production process of the artworks and the production of certain artistic products. Modern material production has a certain degree of socialized large-scale production. The products it produces must have a certain standardization and clear standardization. However, most of the works of art are created by the artist by hand, which is individualized labor. In the process of creating artworks, many artists' inspiration and personal thoughts are combined, and their own personal colors are displayed in the created works. This determines that the production of artworks has a certain personal color and creativity. Artwork can never be normalized or modeled in production, thus escaping the essence of art. Besides, the management of art production activities is different from the management of material production activities in terms of management methods. Although they are all production management activities, they have their own unique management methods and management systems that cannot be replaced with each other.

\subsection{Art management activities must conform to the characteristics of socialist art production relations}

The management of socialist art has a dual nature. It has similarities with historical art management on the one hand. But on the other hand, it is in essence different from historical art management. This distinction is well illustrated in the essence of socialist art production.

Socialism has added a completely new definition to the relationship between art production and management so that it will appear in front of us with a new look. In the early days of art management, the fundamental purpose of art production practitioners in the creation of artistic works was to pursue spiritual aspects, rather than to combine creativity with interests, and in artistic teams, many artistic creations. All of them help each other and there is no dispute of interests.

\section{Subject Research in Art Management}

\subsection{The Mechanism of Art Management}

Whether art management is reasonable, scientific, and perfect in the process of development depends in large part on what it contributes to the development of art. The development of art has a great deal of uniqueness and creativity. It is impossible to find an appropriate management system from the beginning. At this stage, the development of art has entered a new period. The most prominent point is that more scientific management elements have been added to the management of art, so that the scientific management is well integrated with the current art management. At the same time, the development of art and the society must form a situation of simultaneous development. The art field also needs active exploration and continuous innovation and transformation. It can be seen from this that the management mechanism of art has certain inevitability and certain necessity in the process of development. 
The better combination of art management reform and scientification needs both the subject and the object to work together to achieve the desired effect. Standing on the subject of art, we need to fully understand that art is a new emerging discipline. It is not a random derivative of subjective consciousness. Therefore, we need to constantly understand and understand and better develop and master the objective laws in art management. From the perspective of art management, we must recognize the dual nature of art, and do a good job of training and guidance. Moreover, traditional creative ideas cannot be used to constrain the creative enthusiasm and creativity of artistic creators, and it is necessary to make a cautious assessment of the problems that arise during exploration.

\subsection{The Function of Art Management}

The scientific and reasonable art management system requires rigorous main functions, so that the forces that have an influence on the art system can be better developed and contribute more to the development of art management. At this stage, the main body of art management in our country is largely composed of three parts. The first part is the influence of the Party on art management, the second is the influence of the government on art management, and the third is the influence of the mass organizations and leaders on art management.

\subsection{The Employment Principle of Art Managers}

The first point of the principle of employment of art management is to ensure the reasonableness of each position. The second is to ensure that the positions that they manage are not only highly demanding jobs, but also have a broad scope. What is more, art administrators must fully understand the employees' unique characteristics and maximize the plasticity of their positions when they arrange them in a certain position in art management. Finally, while seeing a person's strengths, managers must tolerate their own weaknesses, encourage others' strengths and motivate talents to develop better.

\subsection{The Quality of Art Managers}

\subsubsection{Cultural and artistic accomplishments.}

Cultural cultivation is the cultural connotation and intellectual taste influenced by culture. However, it is not directly equivalent to the level of academic qualifications and the influence of qualifications, mainly reflected in the knowledge and experience, which can be a good example of cultural heritage and cultural connotation. It will result in a small management capacity and lack of management with only continuous learning and accumulation of professional knowledge without understanding the current social forms, common sense or management skills in life. To be a good arts manager, one should have a solid knowledge of art management, read a large number of excellent books, keep abreast of social dynamics, constantly enrich their own life experience, fully grasp the basic-level people's living conditions, and strive to cultivate tough management skills.

\subsubsection{Art administrators' moral character.}

The so-called character cultivation refers to the personality, temperament, appearance, and principles of the art manager's personal qualities. It reflects the artistic manager's values, outlook on life, heart qualities and moral sentiments. Good moral character will be respected and loved by people. Art managers can sum up the methods of excellent quality of cultivation and combine them with their own circumstances to make themselves get better development, gradually improve our own defects in character through continuous and strict demands on ourselves, the cultivation of our own sentiments, and the training of self-cultivation and will. Through the cultivation of character, art managers can promote their own development in the art management field and contribute their own strength to the development of the art industry.

\section{Object Research in Art Management}

The object of artistic management is also an indispensable factor in the development of art 
management. From an objective perspective of art management, we must first fully understand that the development of the socialist art cause cannot be separated from scientific and rational management methods, instead of abandoning all the correct art management because of some problems during the art practice in the past. Secondly, it is necessary to recognize that there is no inevitable contradiction between artistic management and creative innovation and exploration, and that management according to the objective laws of artistic production does not affect the freedom of creation. If the artist better combines the times and the people with creative works, put more humanistic feelings into the works of art, the artistic creation will enter a new era of freedom. It is necessary to firmly grasp the excellent situation under the new era and the main body of art management and guarantee to provide good conditions for creation, create more outstanding works of art, and put personal and collective creative goals in a better construction of the socialist art cause.

\section{Conclusion}

Through the above objective analysis of art management, the difficulty encountered in the development of art at this stage is the lack of artistic talent resources. According to the analysis of the subject of art management, the most prominent problem is that professional arts graduates and administrative graduates account for a larger proportion than those graduated from art management, and their economic management capabilities are insufficient. There is a serious lack of talents with innovative and good marketing capabilities. It can be concluded that there is a need to increase the talent cultivation strategy and vigorously train a group of talents who understand business and management to meet the needs of industrial art development. From the object of artistic development, creating a team with high artistic accomplishment and strong creative ability is an urgent need to vigorously develop art. The majority of art workers need to study hard, enhance ideological and moral qualities and artistic culture, establish correct outlook on life, values and world view, and adhere to the correct scientific artistic creation road, so as to provide better prospects for the rapid development of our country's art career.

\section{References}

[1] Chen Lingling. To Grasp the Aesthetic Nature of Art from the Relationship between Subject and Object, Journal of Changchun College of Education, 2009, 25(03):115-116.

[2] Xiong Wenfei. Discussion on the Relationship between Subject and Object in Design Art, Journal of Mudanjiang Normal University (Philosophy and Social Sciences), 2007(06):125-127.

[3] Chen Xiaojie. The Reflection and Construction of the Relationship between Subject and Object in Art Expression Activities, Qilu Journal, 2006(06):93-97.

[4] Chen Yamin. Observation of the Mutual Harmony of Subject and Object from the Artistic Creation Process, Sun Yatsen University Journal of Literature, 2005(04):293-295.

[5] Ma Longqian. Characteristics and Relations of Subject and Object in Contemporary Chinese Literature and Art, Jiangxi Social Sciences, 2005(06):44-47. 